\title{
AUDIT KOMUNIKASI INSTAGRAM @JOKOWI YANG DIKELOLA OLEH TIM KOMUNIKASI DIGITAL PRESIDEN
}

\section{COMMUNICATION AUDIT OF INSTAGRAM @JOKOWI MANAGED BY THE PRESIDENT'S DIGITAL COMMUNICATION TEAM}

\author{
Andreas Pandiangan', Sella Ikhwanus Shafa² \\ ${ }^{1}$ Universitas Katolik Soegijapranata \\ ${ }^{2}$ Mahasiswa Universitas Katolik Soegijapranata \\ Email: pandiangan@unika.ac.id ${ }^{1}$, shafasella@gmail.com²
}

\begin{abstract}
One of social media that is currently being heavily used is Instagram. Instagram is also used by government public relations in delivering information in the form of images, videos, music, graphics, and much more. The aim is none other than to interact directly with the wider community through cyberspace. Jokowi as a President of Indonesia in carrying out his duties also uses an Instagram account. Such organizational communication both in private or government level need to be evaluated or commonly known as a communication audit. The goal is to find out what the obstacle that occured in the organization between internal or external. Research of Communication Audit of Instagram @jokowi (4 Januari 2016-23 Maret 2019) aimed to analyze the management process of Instagram @jokowi. This study used a qualitative descriptive method by conducting interviews with the management team of Instagram @jokowi, called Tim Komunikasi Digital Presiden. The result will be paired with the observation of the Instagram posts of @jokowi. This study found that the process of communication audit is already good and running in accordance with "Pedoman Umum Audit Komunikasi Di Lingkungan Instansi Pemerintah oleh Peraturan Menteri Pendayagunaan Aparatur Negara dan Reformasi Birokrasi Republik Indonesia Nomor 27 Tahun 2011". This was shown through five analysis units namely organization, management, content of information, communication process and feedback. Communication audit carried out in each organization aim to improve the performance of the organization.
\end{abstract}

Keywords: Organization Communication, Communication Audit, Instagram @jokowi.

\begin{abstract}
Abstrak
Salah satu media sosial yang saat ini sedang marak digunakan adalah Instagram. Instagram juga digunakan oleh humas pemerintah dalam menyampaikan informasi berupa gambar, video, musik, grafik, dan masih banyak lagi. Tujuannya tak lain untuk berinteraksi langsung dengan masyarakat luas melalui dunia maya. Jokowi sebagai Presiden Indonesia dalam menjalankan tugasnya juga menggunakan akun Instagram. Komunikasi organisasi di swasta atau pemerintahan perlu dievaluasi atau biasa dikenal dengan audit komunikasi. Tujuannya untuk mengetahui kendala apa yang terjadi dalam organisasi secara internal maupun ekternal. Riset yang berjudul Audit Komunikasi Instagram @jokowi (4 Januari 2016-23 Maret 2019) ini bertujuan untuk menganalisis bagaimana proses pengelolaan Instagram @Jokowi. Penelitian ini menggunakan metode deskriptif kualitatif dengan melakukan wawancara dengan pengelola Instagram @jokowi yaitu Tim Komunikasi Digital Presiden. Hasilnya akan dipasangkan dengan observasi unggahan Instagram @jokowi. Hasil penelitian ini menggambarkan proses pelaksanaan audit komunikasi yang sudah baik dan berjalan sesuai dengan Pedoman Umum Audit Komunikasi di Lingkungan Instansi Pemerintah yang diatur dalam Peraturan Menteri Pendayagunaan
\end{abstract}


Aparatur Negara dan Reformasi Birokrasi Republik Indonesia Nomor 27 Tahun 2011. Hal tersebut ditunjukkan melalui lima unit analisis yaitu organisasi, manajemen, isi informasi, proses komunikasi dan umpan balik. Audit komunikasi yang dilakukan di setiap organisasi bertujuan untuk meningkatkan kinerja organisasi.

Kata Kunci : Komunikasi Organisasi, Audit Komunikasi, Instagram @jokowi.

\section{PENDAHULUAN}

Keberlangsungan suatu organisasi tidak lepas dari kesinambungan antara pemimpin dengan anggota organisasi tersebut. Seorang pemimpin organisasi atau perusahaan akan mengarahkan anggotanya untuk bekerja sesuai dengan rancangan kerja yang telah direncanakan dalam suatu proyek atau kegiatan. Untuk menilai dan mengetahui apakah kinerja dan proses komunikasi berjalan sesuai dengan aturan kerja dapat dilakukan dengan cara audit. Aspek terpenting dari audit dalam suatu organisasi adalah untuk memeriksa dan menguji data secara sistematik kriteria-kriteria baku yang telah ditetapkan dalam suatu aturan kerja (Hardjana, 2000, p. 6). Berdasarkan Standar Kompetensi Kerja Nasional Indonesia (SKKNI) metode audit komunikasi merupakan cara yang dipilih dan digunakan oleh auditor komunikasi untuk melakukan audit di bidang komunikasi sesuai dengan kebutuhan dalam pemetaan masalah (Permen Ketenagakerjaan 105, 2015, p. 8).

Pada praktiknya audit komunikasi sangat dibutuhkan dalam organisasi untuk mengetahui apa saja hambatan yang terjadi di lingkup organisasi baik secara internal maupun eksternal organisasi. Tujuan audit komunikasi dalam organisasi yaitu untuk memberikan kontribusi dalam proses pembuatan keputusan yang lebih efektif melalui pengayaan sumber informasi internal organisasi guna menghasilkan peningkatan produktivitas kerja (Rosli, 2015, p. 5).

Audit komunikasi tidak hanya dilakukan di lingkup perusahaan swasta akan tetapi juga di lingkungan instansi pemerintah. Menteri Negara Pendayagunaan Aparatur Negara dan Reformasi Birokrasi Republik Indonesia mengeluarkan Peraturan Nomor 27 Tahun 2011 tentang Pedoman Umum Audit Komunikasi di Lingkungan Instansi Pemerintah. Pedoman ini ditetapkan untuk mengoptimalkan kinerja badan publik agar meningkatkan kualitas pelayanan informasi, sehingga keterbukaan informasi bisa tersampaikan dan diakses lebih mudah lagi oleh masyarakat Indonesia (Permen PAN \& RB Nomor 27, 2011, p. i).

Melalui aparatur negara dalam hal ini yang bertindak adalah humas, pemerintah memiliki peran sebagai ujung tombak pengelolaan informasi yang dibangun melalui peningkatan kapasitas dan kompetensi sumber daya manusia (SDM), penguatan struktur dan infrastruktur, sistem dan prosedur, komunikasi organisasi, audit komunikasi, serta manajemen komunikasi krisis, dalam upaya menciptakan tata kelola kehumasan yang baik, sebagai bagian dari tata kelola pemerintahan yang baik.

Dalam pedoman kehumasan, manajemen kehumasan terdiri dari manajemen kehumasan dalam sistem komunikasi terbuka dan sistem komunikasi tertutup. Manajemen kehumasan dalam sistem komunikasi terbuka merupakan proses komunikasi dua arah yang mendengarkan umpan balik dari publik. Sedangkan manajemen kehumasan dalam sistem komunikasi tertutup hanya melakukan fungsi komunikasi satu arah dengan publik yang berkepentingan. 
Terdapat 11 klasifikasi publik yang dikelola dalam kehumasan. Salah satunya yaitu publik eksternal sekunder yang terbagi menjadi tiga bagian; mitra instansi pemerintah pusat dan daerah, media massa yang meliputi media cetak seperti majalah dan buletin, media elektronik seperti radio dan televisi, serta online seperti media sosial Twitter, Facebook, Instagram, dan lain-lain, serta lembaga lainnya (Permen PAN \& RB Nomor 27, 2011, p. 20).

Di tengah maraknya media komunikasi yang beredar saat ini, humas pemerintah dituntut untuk dapat memilih dan menggunakan media mana yang baik dan tepat bagi publik internal maupun publik eksternal. Saat ini semakin banyak masyarakat yang menggunakan internet, komunikasi melalui media online menjadi salah satu yang paling digemari. Di tahun 2018, masyarakat pengguna internet meningkat sekitar delapan persen menjadi 143,26 juta jiwa. Ini setara dengan 54,68 persen dari populasi 262 juta orang. Jenis layanan yang sering diakses pengguna yaitu aplikasi chatting dengan 89,35 persen. Kemudian disusul media sosial dengan 87,13 persen, mesin pencari dengan 78,84 persen dan sisanya aktivitas internet lain (APJII, 2018, p. 1). Dalam konteks dunia, Indonesia berada di peringkat ke-8 di dunia dengan 82 juta orang pengguna internet (Ajo, 2018).

Jumlah ini menunjukkan betapa besarnya potensi media sosial sebagai media komunikasi dan penyebaran informasi tak terkecuali bagi humas pemerintah. Media sosial dapat menjadi salah satu cara dalam mempromosikan serta menyebarluaskan program dan kebijakan pemerintah serta berinteraksi dan menyerap aspirasi masyarakat sehingga tercipta pengertian untuk kepentingan bersama antara pemerintah dan masyarakat.

Salah satu bentuk media sosial yang saat ini gencar digunakan adalah Instagram. Instagram juga digunakan oleh humas pemerintah untuk menyampaikan informasi baik berupa gambar, video, musik, grafik, dan masih banyak lagi. Tujuannya tidak lain yaitu untuk berinteraksi dengan masyarakat luas secara langsung melalui dunia maya.

Presiden Jokowi selaku Kepala Negara sekaligus Kepala Pemerintahan, dalam menjalankan tugasnya juga menggunakan akun Instagram. Akun Instagram @jokowi memiliki aktivitas yang lebih tinggi dibandingkan dengan akun media sosial lain miliknya, dilihat dari banyaknya jumlah pengikut yang mencapai 20,3 juta orang. Sedangkan Twitter @jokowi diikuti 11 juta orang, Facebook Presiden Jokowi disukai oleh 9,3 juta orang dan akun Youtube Presiden Joko Widodo diikuti 1,3 juta subscriber. Tidak hanya dari jumlah pengikut yang lebih banyak akan tetapi akun Instagram @jokowi juga mendapat lebih banyak umpan balik atau feedback yang bahkan bisa mencapai satu juta likes (orang menyukai) dalam satu unggahan. Hal tersebut tidak terjadi di media sosial Presiden Jokowi lainnya.

Sebagaimana akun media sosial Presiden Jokowi yang lain, akun Instagram @jokowi juga dikelola oleh Tim Komunikasi Digital Presiden. Hal ini telah diklarifikasi oleh Presiden Jokowi. Selain itu, pada 28 Januari 2016 akun tersebut telah mendapatkan verifikasi resmi dari pihak Instagram. Foto yang diunggah Jokowi dalam akun Instagram miliknya adalah foto-foto aktivitasnya sehari-hari seperti memimpin rapat, menerima tamu kenegaraan, dan kunjungan kerja ke berbagai daerah (Nistanto, 2016).

Dalam konteks komunikasi organisasi lembaga Kepresidenan itulah dibutuhkan audit komunikasi terhadap akun media sosial Instagram @jokowi periode 4 Januari 2016 hingga 23 Maret 2019.

Organisasi yang berkembang di masyarakat tidak lepas dari sistem dan proses komunikasi yang ada di dalamnya. Guetzkow dalam Hardjana (2016, p. 37) mengatakan bahwa 
selain berfungsi sebagai jaringan yang menghubungkan anggota-anggota organisasi menjadi satu kesatuan, sistem komunikasi juga berfungsi sebagai alat yang membuat organisasi mengait pada lingkungannya.

Interaksi internal dan eksternal organisasi memerlukan kebutuhan adanya komunikasi organisasi. Dimana terjadi pertunjukan dan penafsiran pesan di antara unit-unit komunikasi yang merupakan bagian dari suatu organisasi tertentu. Suatu organisasi terdiri dari unit-unit komunikasi yang terdiri dari unit-unit komunikasi dalam hubungan-hubungan hierarkris antara yang satu dan lainnya dan berfungsi dalam suatu lingkungan ( Wayne, 2000, p. 20).

Ruang lingkup komunikasi organisasi dapat dibedakan berdasarkan penerima pesan. Dari segi 'penerima' pesan, komunikasi dapat dibedakan menjadi komunikasi internal yang melibatkan anggota-anggota organisasi sebagai penerima pesan dan komunikasi eksternal yang melibatkan orang-orang di luar organisasi. Melalui komunikasi eksternal pimpinan organisasi menaruh perhatian khusus terhadap perkembangan teknologi yang dapat memengaruhi pembentukan citra (image building) suatu organisasi. Hal ini dapat ditangani dengan penggunaan media sosial sebagai jembatan untuk berkomunikasi antara organisasi dengan masyarakat. Di samping itu, dari perspektif intepretatif (subjektif) komunikasi organisasi juga dipandang sebagai proses penciptaan makna atas interaksi yang merupakan organisasi. Komunikasi organisasi adalah perilaku pengorganisasian yang terjadi dan bagaimana pihakpihak yang terlibat di dalamnya bertransaksi dan memberikan makna atas apa yang sedang terjadi ( Hardjana, 2016, p. 36).

Pelaksanaan komunikasi organisasi perlu mendapatkan evaluasi secara periodik. Mengapa evaluasi perlu dilakukan? Agar diperoleh gambaran lengkap apakah komunikasi organisasi sudah dapat membantu tujuan keberadaan organisasi pemerintah dan atau swasta/ perusahaan. Salah satu cara melakukan evaluasi adalah melalui audit komunikasi.

Audit komunikasi merupakan suatu riset evaluasi yang dikembangkan International Communication Association (ICA). Gerald Goldhaber mengatakan bahwa audit komunikasi adalah seperangkat teknik analisis ilmiah yang menyeluruh untuk merencanakan intervensi dan mengembangkan strategi-strategi perbaikan komunikasi. Audit komunikasi adalah pelaksanaan diagnosis sistem komunikasi organisasi. Seperti halnya dalam pemeriksaan umum yang dilakukan oleh para akuntan dan para dokter yang dapat memberikan informasi kesehatan yang dibutuhkan kepada kliennya, demikian pula audit komunikasi ini memberikan informasi dini kepada organisasi agar dapat mencegah terjadinya bencana pada organisasi (Hardjana, 2000, p. 13).

Audit komunikasi dalam suatu organisasi perlu dilakukan guna meningkatkan efektivitas sistem komunikasi organisasi. Hal ini berlaku juga bagi organisasi pemerintah maupun swasta. Audit komunikasi bisa dilakukan kapan saja, pada saat, dan diantara dimensi persoalan dan perencanaan (problem-planning dimension). Pada satu sisi, audit komunikasi dapat dilakukan bila muncul suatu persoalan besar yang harus dipecahkan dalam suatu organisasi, sedangkan di sisi lain, audit komunikasi juga dibutuhkan untuk memperoleh gambaran pada saat ini terhadap pengembangan perencanaan komunikasi. Audit komunikasi dapat digunakan untuk merencanakan apa sasaran atau tujuan untuk enam bulan mendatang atau pada periode tertentu dan bagaimana cara mencapai sasaran tersebut (Hardjana, 2000, p. 20).

Menurut Hardjana (2000), efektivitas pelaksanaan sistem komunikasi dapat ditinjau dari lima faktor penting diantaranya yaitu organisasi, manajemen, muatan informasi, proses 
komunikasi atau kegiatan-kegiatan komunikasi dan umpan balik (feedback) yang dapat dijadikan pokok peninjauan dalam audit komunikasi kehumasan (p. 163-166).

Pertama, organisasi. Setiap organisasi memiliki kebijakan, peraturan, prosedur, peralatan mekanik-elektronik, dan sumber daya manusia untuk menangani komunikasi, agar komunikasi dapat berfungsi dengan baik sebagaimana mestinya. Misalnya saja seorang staf humas pusat disamping harus mengetahui bagaimana sistem yang berlaku di perusahaan atau instansi tersebut, juga perlu melakukan hubungan dan kontak langsung dengan mereka yang bekerja di lapangan, karena mereka itulah yang menjadi juru bicara ketika menghadapi masyarakat sekitarnya.

Kedua manajemen. Tanpa keterbukaan manajemen komunikasi organisasi akan mengalami kesulitan baik komunikasi dengan segenap anggota organisasi maupun dengan masyarakat lingkungannya. Setiap unit dalam organisasi perlu diwawancarai mengenai hubungan masyarakat dan komunikasi internal organisasi. Sehingga dari jawaban mereka dapat disusun sebuah pandangan atau filsafat organisasi yang berguna untuk dijadikan pengembangan program, baik dalam pembuatan kebijakan kehumasan ataupun pengerahan dukungan untuk perubahan kebijakan yang ada.

Ketiga, muatan informasi, dimana keterbukaan antar-divisi dalam organisasi dapat menciptakan suasana yang kondusif dalam proses penyampaian informasi. Dukungan media komunikasi tertulis dan elektronik sangat menunjang mereka dalam hal efisiensi waktu, penggunaan teknologi dan sistem jaringan komputer agar informasi yang disampaikan kepada publik bisa sesuai dan tepat sasaran.

Keempat, proses komunikasi atau kegiatan-kegiatan komunikasi. Proses komunikasi dalam organisasi dapat dibedakan menjadi dua, yakni komunikasi objektif dan komunikasi subjektif. 'Komunikasi objektif' berkaitan dengan fakta-fakta yang menjadi perhatian segenap unit dan dapat diperiksa kebenarannya (accuracy). 'Komunikasi subjektif' berkaitan dengan berbagai ide pemikiran, peraturan, anggapan terhadap kritikan, perencanaan, penjelasan tentang kebijakan dan tindakan tertentu. Audit komunikasi secara seksama, objektif, dan kritis menyimak isi dan kualitas dari press release atau siaran pers, pidato-pidato dan ceramah, penerbitan-penerbitan berkala, laporan keuangan dan lain-lain.

Kelima, umpan balik (feedback) yang menjadi pokok terpenting yang harus diperhatikan sebagai petunjuk tentang bagaimana komunikasi yang dilakukan oleh manajemen agar dapat diterima oleh masyarakat luas di luar organisasi. Hal ini juga berkaitan dengan seperti apa citra organisasi yang diharapkan oleh pihak manajemen dalam persepsi masyarakat dan bagaimana kenyataan citra itu sekarang menurut perkiraan manajemen.

Selain kelima unit analisis mengenai audit komunikasi yang telah dijabarkan di atas, ada beberapa hal yang berkaitan dengan etika selama kegiatan audit komunikasi tersebut berlangsung. Rekomendasi-rekomendasi yang dibuat oleh pengaudit berdasarkan hasil audit yang telah ditelitinya harus memerhatikan etika pribadi maupun etika profesional agar etika organisasi dalam melaksanakan langkah-langkah perbaikan tidak bertentangan dengan etika masyarakat.

Di lingkungan pemerintah, audit komunikasi telah diatur dalam Pedoman Umum Audit Komunikasi di Lingkungan Instansi Pemerintah yang dikeluarkan Kementerian Pendayagunaan Aparatur Negara dan Reformasi Birokrasi Republik Indonesia melalui Peraturan Menteri Negara Pendayagunaan Aparatur Negara dan Reformasi Birokrasi Republik Indonesia Nomor 27 Tahun 
2011. Pedoman Umum Audit Komunikasi disusun sebagai acuan dalam mengukur sistem komunikasi yang akurat dan andal di lingkungan instansi pemerintah sehingga mampu mengatasi kesenjangan antara perencanaan dan pelaksanaan, serta harapan publik dengan tujuan instansi pemerintah. Melalui Pedoman Audit Komunikasi ini diharapkan keterbukaan komunikasi instansi pemerintah yang sesuai dengan harapan publik dapat terwujud (Permen PANRB Nomor 27, 2011, p. pengantar).

Audit komunikasi di instansi pemerintah dikelola oleh divisi humas yang bertugas untuk mengkaji tentang kebutuhan dan praktik komunikasi kehumasan, dengan menggunakan metode-metode penelitian untuk melakukan analisis atas tujuan-tujuan organisasi dan menghubungkan tujuan-tujuan tersebut dengan kegiatan komunikasi yang berlangsung.

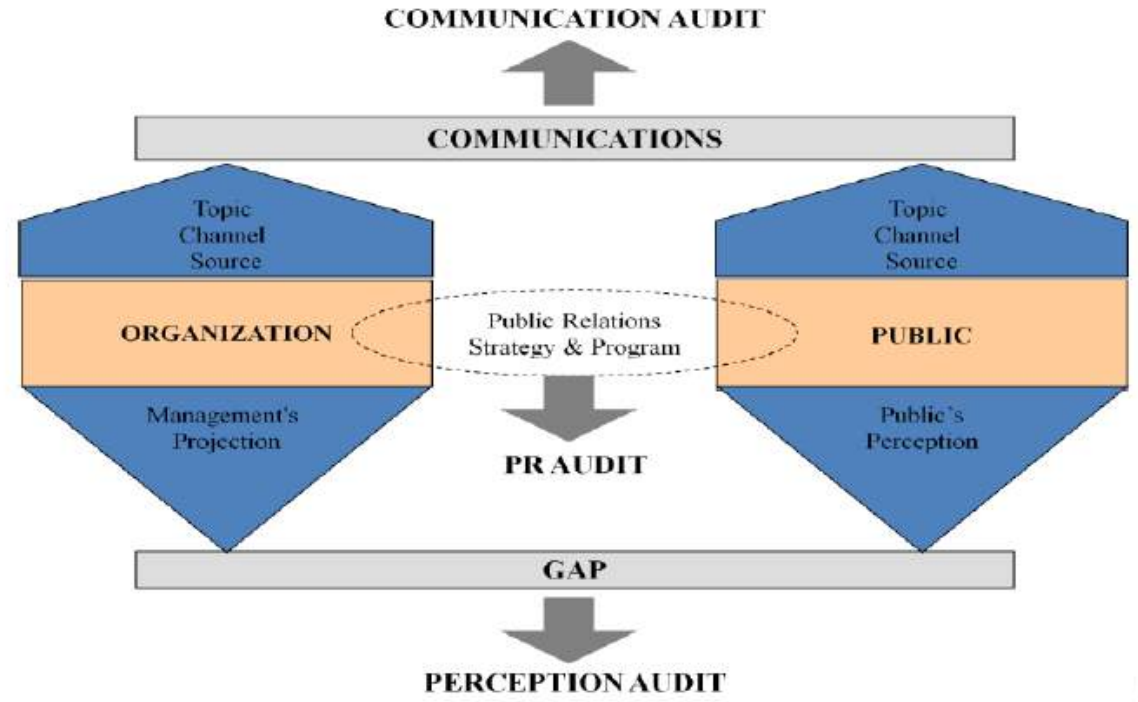

Gambar 1. Konsep Umum Audit Komunikasi

Sumber: Pedoman Umum Audit Komunikasi Di Lingkungan Instansi Pemerintah, Permen PANRB Nomor 27, 2011.

Untuk mencapai visi dan misi serta tujuan, instansi pemerintah dalam melakukan kegiatan operasional sehari-hari tidak lepas dari interaksi dengan publik (Gambar 1). Hal ini dilakukan agar tercipta kondisi yang selaras dan mendapat dukungan dari publik melalui strategi dan program kehumasan yang dijalankan. Tidak jarang kesenjangan komunikasi yang terjadi berdampak terhadap persoalan kepercayaan (trust).

Untuk mengurangi tingkat kesalahpahaman, maka diperlukan audit komunikasi yang bertujuan meningkatkan efektivitas sistem dan proses komunikasi humas pemerintah. Audit komunikasi ini mengukur, menganalisis, serta mengevaluasi secara mendalam dan menyeluruh sistem serta proses komunikasi instansi pemerintah (Permen PANRB Nomor 27, 2011, p. 9).

Audit komunikasi dapat dilakukan dengan memerhatikan beberapa dimensi yang meliputi proses penyampaian pesan, gaya komunikasi, model komunikasi yang diterapkan antara instansi pemerintah dan publiknya, saluran komunikasi, media komunikasi, ketepatan waktu, frekuensi komunikasi, kejelasan arti pesan, keterbukaan dan kejujuran, partisipasi anggota instansi pemerintah dan publik, umpan balik publik, peran dan fungsi masing-masing anggota instansi pemerintah dalam berbagai kelompok, pemecahan masalah dan pembuatan 
putusan, norma-norma yang digunakan, kepemimpinan dan kewenangan, serta penghargaan dan sanksi (Permen PANRB Nomor 27, 2011, p. 10-11).

Melalui audit komunikasi dapat diketahui efektivitas proses komunikasi, gaya, model, saluran, media, waktu, kejelasan pesan, keterbukaan dan kejujuran, partisipasi anggota instansi pemerintah dan publik, umpan balik, serta pengharapan dan sanksi yang digunakan instansi pemerintah dalam berinteraksi dengan indikator sejauh mana baik anggota instansi pemerintah maupun publik bisa memahami pesan serta memberikan tanggapan (respons) (Hardjana, 2000, p. 10-11). Dimensi audit komunikasi tersebut sudah mencakup ke dalam lima unit analisis seperti yang dianjurkan oleh ICA (International Communication Association).

Prosedur audit komunikasi di instansi pemerintah diterapkan pada level sistem komunikasi keseluruhan dan pada level kegiatan komunikasi khusus. Setiap audit komunikasi diawali dengan audit sistem komunikasi secara keseluruhan dan dilanjutkan dengan audit kegiatan komunikasi khusus untuk memenuhi harapan publik dan tercapainya program komunikasi di instansi pemerintah.

Populasi pengguna internet di Indonesia kian hari kian meningkat seiring dengan meningkatnya pembangunan infrastruktur teknologi informasi dan didukung program pemerintah yang memperkenalkan sarana internet hingga ke pelosok Indonesia. Pertumbuhan pengguna internet semakin berlipat ganda seiring dengan pertumbuhan penjualan telepon seluler pintar (smartphone) yang dapat mengakses internet bergerak (mobile) di mana saja dan kapan saja.

Patrice Randle, seorang auditor di kota Arlington Amerika Serikat, menyatakan bahwa penggunaan media sosial secara efektif dapat dijadikan sebagai sarana untuk mempromosikan merek (brand) suatu kota atau negara. Media sosial digunakan untuk melibatkan warga dalam berbagai kebijakan yang diatur oleh departemen-departemen yang ada di Kota Arlington (Randle, 2013, p. 3).

Penggunaan media sosial telah membentuk dan mendukung cara baru dalam berkomunikasi, berinteraksi, dan berkolaborasi. Media sosial menawarkan yang lebih cepat dan tepat untuk berpartisipasi dalam pertukaran informasi melalui daring (dalam jaringan atau online). Termasuk di lingkungan pemerintahan.

Humas pemerintah menggunakan berbagai media komunikasi berbasis internet, seperti situs, portal berita, blog dan media sosial. Bahkan media sosial menjadi salah satu yang sering digunakan baik oleh perorangan maupun organisasi/ lembaga. Sifat media sosial yang dua arah dan terbuka memungkinkan para penggunanya dengan mudah dapat berpartisipasi, berbagi dan menciptakan isi (Permen PANRB Nomor 83, 2012, p. 2).

Saat ini hampir seluruh lembaga pemerintah telah menggunakan satu atau lebih media sosisal sebagai sarana komunikasi kehumasan. Media sosial terbukti mampu melibatkan khalayak secara aktif dan menjaring masukan dari berbagai kalangan sehingga menciptakan kearifan orang banyak (wisdom of the crowd). Akan tetapi, apabila tidak dikelola dengan baik dan bijak maka penggunaan media sosial sebagai alat komunikasi kehumasan dapat membawa dampak negatif. Sehingga berbagai komentar dan masukan baik yang positif maupun negatif bisa masuk tanpa dapat dikendalikan dan akan memengaruhi citra lembaga tersebut.

Kini banyak bermunculan akun-akun yang mengatasnamakan instansi pemerintah yang sebenarnya bukan akun resmi lembaga yang bersangkutan, melainkan akun individu pegawai atau pihak-pihak yang tidak bertanggungjawab. Apabila hal ini dibiarkan dan tidak disertai 
aturan dan pengendalian yang tegas dan mengikat serta pengelolaan yang profesional, maka dapat mengakibatkan ketidakjelasan pesan dan kebingungan khalayak yang akan berdampak juga terhadap citra lembaga yang bersangkutan.

\section{METODOLOGI PENELITIAN}

Audit komunikasi sebagai bagian penelitian deskriptif kualitatif (Sugiyono, 2016, p. 1-2), dilakukan terhadap Instagram @jokowi yang dikelola oleh Tim Komunikasi Digital Presiden (TKDP). Unggahan (post) Instagram merupakan muatan informasi (Kriyantono, 2006, p. 41). Selama periode 4 Januari 2016 (yang mana tanggal tersebut merupakan tanggal awal dari unggahan @jokowi) hingga 23 Maret 2019 atau sehari sebelum Presiden Jokowi mengikuti kampanye terbuka pada pemilihan umum presiden dan wakili presiden (Pilpres) terdapat sebanyak 1.141 unggahan.

Unit analisis dalam audit komunikasi meliputi organisasi, manajemen, muatan informasi, proses komunikasi atau kegiatan-kegiatan komunikasi, dan umpan balik. (Hardjana, 2000, p. 163-166).

Sebelum melakukan kegiatan audit, ada tiga langkah pra-audit yang penting untuk dilakukan dan hal ini saling berkaitan satu sama lain (Sugiyono, 2016, p. 132-135) yaitu kontak hubungan, pertemuan persiapan, dan pembuatan kontrak. Sementara langkah-langkah audit komunikasi mencakup 7 dari 14 langkah (Hardjana, 2000) yang umumnya dilakukan oleh pengaudit komunikasi sebagaimana dianjurkan oleh International Communication Association (ICA) (Sugiyono, 2016, p. 137-139).

Tujuh langkah audit komunikasi tersebut di antaranya: 1) Studi kelayakan; 2) pertemuan perkenalan; 3) alat-alat pengukuran profil, termasuk pendalaman akan organisasi pengelolaan, manajemen, muatan informasi, proses komunikasi atau kegiatan komunikasi dan umpan balik; 4) tindak lanjut dari penggunaan alat-alat pengukuran profil, dengan melakukan wawancara dengan memerhatikan catatan kegiatan komunikasi harian dan daftar periksa yang bisa berupa batasan berapa jumlah konten yang ditayangkan setiap harinya; 5) pengumpulan data dari unitunit yang saling melengkapi, termasuk melakukan wawancara dengan TKDP; 6) pertemuan untuk analisis data. Setelah memperoleh data dari pihak terkait dan unit pelengkap maka kemudian dilakukan elaborasi lebih lanjut dan menentukan mana saja masalah-masalah yang terjadi dari topik yang diteliti; 7) laporan akhir yang memaparkan hasil dan penyampaian rekomendasi serta saran perbaikan bagi pengelolaan akun Instagram @jokowi sebagai tujuan pokok dari penyelenggaraan audit komunikasi.

\section{HASIL DAN PEMBAHASAN}

\section{Organisasi}

Sama seperti akun media sosial Presiden Jokowi lainnya, akun Instagram @jokowi dikelola oleh tim khusus. Nama tim tersebut adalah Tim Komunikasi Digital Presiden (TKDP) yang berada di bawah naungan Kementerian Sekretariat Negara Republik Indonesia dan berkantor di Jalan Veteran No. 17-18, Jakarta Pusat. Anggota TKDP dipilih sendiri Presiden Joko Widodo (Jokowi) dan bertugas untuk mengelola akun media sosial Presiden. Hingga saat riset ini dilakukan, TKDP sudah mengalami dua periode kepengurusan. Pertama, sejak Presiden Jokowi memiliki akun resmi media sosial pada 23 November 2015 hingga Desember 2016. 
Kedua, sejak Januari 2017 hingga 23 Maret 2019, sehari sebelum Presiden Jokowi mengikuti kampanye terbuka Pemilihan Umum Presiden/ Wakil Presiden (TKDP, 2019, p. 1).

Visi dan misi TKDP yakni agar pemikiran, semangat dan Visi Presiden untuk "Indonesia Maju" menjadi semangat, visi dan inspirasi seluruh masyarakat Indonesia. Sehingga tugas besar dari Tim Komunikasi Digital Presiden adalah membantu Presiden untuk menyampaikan informasi secara akurat, menarik, dan kekinian kepada masyarakat Indonesia melalui kanal digital tentang kegiatan, pemikiran, semangat dan visi Presiden.

TKDP diisi para ahli dan profesional di bidang media sosial dan digital. Struktur TKDP terdiri dari tiga tim yaitu Tim Strategi Komunikasi, Tim Konten, dan Tim Analisis Data. Organisasi Tim Komunikasi Digital Presiden saat ini diisi oleh mereka yang berpengalaman dan profesional di bidang media sosial dan di bidang digital secara umum. Kriteria khusus dalam memilih anggota Tim Komunikasi Digital Presiden adalah orang yang profesional, berpengalaman, produktif, kreatif dan mampu bekerja cepat sesuai etos kerja cepat dari Presiden Jokowi (TKDP, 2019, p. 1-2).

Tugas dan fungsi utama TKDP adalah untuk membantu Presiden dalam menyampaikan informasi secara akurat, menarik dan kekinian kepada masyarakat Indonesia mengenai kegiatan, pemikiran, semangat dan visi Presiden untuk "Indonesia Maju" melalui kanal resmi media sosial Presiden termasuk Instagram @jokowi. Saat menjalankan tugasnya, Tim Komunikasi Digital Presiden juga berfungsi dalam menyampaikan hasil kinerja pemerintahan sehingga masyarakat bisa mengetahui sampai dimana progress kinerja yang dilakukan pemerintahan. Apabila tugas-tugas tersebut dilakukan dengan baik maka diharapkan semangat dan visi Presiden untuk percaya diri dan berani menuju "Indonesia Maju" dapat menginspirasi, menyebar dan dipahami oleh masyarakat Indonesia. Saat menjalankan tugasnya, Tim Komunikasi Digital Presiden bekerja dengan mitra kerja internal dan eksternal organisasi seperti Biro Pers Kepresidenan, Sekretariat Kabinet dan Sekretariat Negara yang juga menjadi sumber dalam penerimaan informasi terkait kegiatan dan agenda Presiden Jokowi (TKDP, 2019, p. 3).

\section{Manajemen}

Alur produksi konten yang diunggah di Instagram @jokowi adalah 1) dimulai dari pencarian ide secara bersama oleh tim, kemudian pengujian, pengemasan dan memutuskan ide terpilih oleh tim; 2) perumusan narasi konten, termasuk karakter dan lokasi, sesuai ide yang terpilih; 3) perumusan skenario konten sesuai narasi konten dengan mempertimbangkan sumber daya dan waktu yang ada; 4) membuat rincian jadwal perjalanan shooting termasuk kebutuhan transportasi, akomodasi, perizinan, dan peralatan shooting; 5) proses liputan; 6) kegiatan pasca-liputan yang meliputi editing-uji, kualitas-input dari tim re-editing dan seterusnya melakukan iterasi yang sama sampai didapatkan hasil dengan kualitas yang baik menurut tim (TKDP, 2019, p. 3).

\section{Muatan informasi}

Akun Instagram @jokowi dibuat pada 23 September 2015, tetapi tidak langsung diisi dengan unggahan. Baru pada tanggal 4 Januari 2016 pihak TKDP mengunggah foto kegiatan Presiden Jokowi untuk pertama kalinya yang terkait pembangunan infrastruktur. Pembangunan infrastruktur ini yang menjadi fokus yang sering ditampilkan dalam perkembangan Instagram @jokowi yang kemudian disusul dengan kategori unggahan berupa ucapan. Dalam kurun 
waktu 4 Januari 2016 hingga 23 Maret 2019 terdapat 1.141 postingan. Jumlah kegiatan dalam unggahan-unggahan itu tidak sepenuhnya mencerminkan kegiatan yang dilakukan Presiden Jokowi. Tabel 1 di bawah ini menunjukkan dinamika sebaran konten yang diunggah di Instagram@jokowi.

Tabel 1. Jumlah Unggahan Instagram @jokowi (4 Januari 2016 sampai dengan 23 Maret 2019)

\begin{tabular}{|c|c|c|c|c|c|c|}
\hline \multirow{2}{*}{ No. } & \multirow{2}{*}{ Bulan } & \multicolumn{4}{|c|}{ Tahun } & \multirow{2}{*}{ Total } \\
\hline & & 2016 & 2017 & 2018 & 2019 & \\
\hline 1. & Januari & 40 & 32 & 11 & 57 & 140 \\
\hline 2. & Februari & 5 & 37 & 12 & 60 & 114 \\
\hline 3. & Maret & 21 & 19 & 22 & 71 & 133 \\
\hline 4. & April & 23 & 2 & 12 & - & 37 \\
\hline 5. & Mei & 16 & 19 & 18 & - & 53 \\
\hline 6. & Juni & 14 & 14 & 34 & - & 62 \\
\hline 7. & Juli & 11 & 9 & 54 & - & 74 \\
\hline 8. & Agustus & 18 & 14 & 74 & - & 106 \\
\hline 9. & September & 19 & 9 & 65 & - & 93 \\
\hline 10. & Oktober & 26 & 9 & 69 & - & 104 \\
\hline 11. & November & 36 & 7 & 58 & - & 101 \\
\hline \multirow[t]{2}{*}{12.} & Desember & 37 & 20 & 67 & - & 124 \\
\hline & Jumlah & 266 & 191 & 496 & 188 & 1.141 \\
\hline
\end{tabular}

Sumber: Olah data postingan Instagram @jokowi (4 Januari 2016 hingga 23 Maret 2019)

Sejumlah 1.141 unggahan pada akun Instagram @jokowi dari 4 Januari 2016 hingga 23 Maret 2019 dikelompokkan ke dalam 19 kategori sebagaimana disajikan dalam Tabel 2 di bawah ini:

Tabel 2. Kategorisasi Unggahan Instagram @jokowi

\begin{tabular}{clc}
\hline No. & \multicolumn{1}{c}{ Kategorisasi } & Jumlah \\
\hline 1. & Pembangunan Infrastruktur & 243 \\
2. & Ucapan & 222 \\
3. & Sosial Budaya & 180 \\
4. & Ekonomi & 98 \\
5. & Rapat Kerja & 62 \\
6. & Kunjungan Kenegaraan & 50 \\
7. & Menerima Kunjungan Kenegaraan & 43 \\
8. & Kehidupan Pribadi & 42 \\
9. & Prestasi & 42 \\
10. & Bencana & 32 \\
11. & Menerima Kunjungan Tamu Dalam Negeri & 32 \\
12. & Pertahanan \& Keamanan & 26 \\
13. & Pendidikan & 20 \\
14. & Pelantikan & 11 \\
15. & Tenaga Kerja & 10
\end{tabular}




\begin{tabular}{llc} 
16. & Upacara & 10 \\
17. & Pariwisata & 8 \\
18. & Kesehatan & 5 \\
19. & Lingkungan Hidup & 5 \\
\hline & Total & $\mathbf{1 . 1 4 1}$ \\
\hline
\end{tabular}

Sumber: Olah data postingan instagram @jokowi (4 Januari 2016-23 Maret 2019)

Berdasarkan tabel di atas, kategori pembangunan infrastruktur memiliki jumlah pemberitaan terbanyak yakni 243. Pemberitaan tersebut di antaranya peninjauan hingga peresmian pembangunan gedung, pasar, jalan, transportasi, dan ruang publik lainnya yang ada di berbagai pelosok Indonesia termasuk kegiatan penyerahan sertifikat tanah yang dilakukan oleh Presiden Jokowi. Peresmian terminal Petikemas Kalibiru, kereta api Jakarta-Manggarai, kereta MRT di Jakarta, kereta bandara Kualanamu-Medan, Bandara Wamena di Papua, Pelabuhan di Wasior Papua Barat, dan jembatan Merah Putih di Ambon juga masuk dalam kategori ini. Termasuk pembangunan 7 Pos Lintas Batas Negara (PLBN), pembangunan waduk dan bendungan, revitalisasi pasar tradisional yang tersebar di seluruh pelosok Indonesia. Hingga pembangunan tol agar seluruh sudut pusat industri dan perekonomian di Nusantara dapat terhubung. Seperti tol ruas Medan-Kualanamu, ruas Surabaya-Mojokerto, ruas BalikpapanSamarinda, ruas Pejagan-Pemalang, ruas Pemalang-Batang, ruas Bogor-Ciawi-Sukabumi, ruas Salatiga-Solo dan ruas lainnya di trans Jawa. Pembangunan infrastruktur menjadi fokus dalam tampilan Instagram @jokowi.

Kategori terbesar kedua adalah ucapan. Mencakup ucapan pada hari besar seperti Hari Kemerdekaan Republik Indonesia, Hari Pendidikan, Hari Besar Keagamaan. Termasuk saat Presiden Jokowi memberikan ucapan ulang tahun kepada beberapa tokoh publik seperti kepada B. J. Habibie. Juga ucapan selamat bertanding untuk para atlet yang akan berlaga hingga ucapan duka cita mengenang kepergian tokoh dari dalam maupun luar negeri, serta berbagai macam ucapan penting lainnya. TKDP menjadikan akun Instagram @jokowi ini sebagai media untuk menginformasikan dan menyampaikan pesan dari Presiden Jokowi kepada masyarakat Indonesia.

Sosial budaya menjadi kategori terbesar ketiga. Kategori ini memuat kegiatan Presiden Jokowi saat mengunjungi daerah tertentu dalam rangka kegiatan sosial dan budaya, seperti di Bali. Termasuk kegiatan khas Jokowi yang dikenal sebagai blusukan. Saat blusukan, Jokowi bertemu atau tatap muka secara langsung dengan masyarakat di berbagai daerah di Indonesia di luar perencanaan kunjungan dan di luar protokuler Kepala Negara. Melalui blusukan, Jokowi ingin membangun komunikasi politiknya secara langsung sehingga masyarakat dapat menyampaikan keluh kesah kepada Presiden Jokowi.

Ekonomi sebagai kategori terbesar keempat menampilkan kegiatan Presiden Jokowi saat menghadiri atau membahas topik mengenai kondisi perekonomian Indonesia seperti menggerakkan ekonomi desa melalui program Badan Usaha Milik Desa (BUMDes) di daerah Polewari Mandar, Sulawesi Barat, usaha Indonesia menguasai saham Freeport sebanyak $51,23 \%$, pemberdayaan perempuan melalui program MEKAAR (pinjaman modal usaha), pemberian Dana Desa yang meningkat tiap tahunnya, hingga mendorong tumbuhnya usaha mikro, kecil dan menengah (UMKM) yang mampu menyejahterakan masyarakat Indonesia. 
Sementara itu kategori rapat kerja memuat berbagai unggahan dimana masyarakat dapat mengetahui dan memantau kegiatan rapat kerja Presiden Jokowi. Salah satu rapat yang favorit dilakukan oleh Presiden Jokowi adalah Rapat Terbatas (Ratas). Bila Presiden Jokowi tidak keluar Jakarta maka Ratas biasanya dilakukan antara 2-3 kali dengan durasi sekitar 1-3 jam. Beragam isu dan masalah yang dibahas menghasilkan keputusan pemerintah. Sayangnya hasil Ratas tidak selalu diberitakan oleh humas kementerian/ lembaga yang terkait, minimal di situs masing-masing.

Kategori kunjungan kenegaraan dan kategori menerima kunjungan kenegaraan diposisikan sebagai 'jendela' bagaimana relasi Indonesia di bawah kepemimpinan Presiden Jokowi di dunia internasional baik dalam konteks hubungan bilateral dan multilateral. Serta tidak terbatas pada hubungan negara/ pemerintah saja tetapi juga hubungan dengan lembagalembaga internasional dan para pemodal manca negara. Harapannya ada dampak positif bagi perkembangan ekonomi Indonesia.

Unggahan Instagram @jokowi tidak hanya memuat kegiatan formal-informal kenegaraan Presiden Jokowi. Tapi juga ada yang memuat postingan seputar kehidupan pribadi dengan unggahan 42 kali. Unggahan tersebut menampilkan aktivitas pribadi Presiden Jokowi di luar jam dinasnya seperti saat duduk santai dan menikmati gerhana matahari dari halaman Istana Bogor atau memelihara domba di area Istana Bogor. Berjalan-jalan di mall dan menonton film terbaru Indonesia bersama keluarga. Berolahraga seperti futsal melawan Tim Kepresidenan dan wartawan Istana. Melangsungkan pernikahan anaknya yang kedua yaitu Kahiyang Ayu di tahun 2017. Hingga mengajak Jan Ethes cucunya untuk bermain-main baik di mall maupun tempat wisata lainnya. Hal yang menarik adalah dari sekian kategori tentang kehidupan pribadi Presiden, kebersamaan dengan Jan Ethes cucunya menjadi konten yang cukup sering diunggah dan tentunya mendapat perhatian yang tinggi dari netizen atau masyarakat.

Kategori prestasi memuat kegiatan Presiden Jokowi saat memberikan penghargaan kepada tokoh berprestasi seperti atlet Asian Games dan atlet Asian Para Games tahun 2018, pegiat seni, siswa berprestasi, hingga menyampaikan prestasi yang diperoleh Indonesia di kancah Internasional. Selain itu juga prestasi diberikan kepada pendonor darah yang sudah sangat loyal dalam berkontribusi dan membantu masyarakat Indonesia yang membutuhkan.

Sementara kategori bencana memuat kegiatan Presiden Jokowi saat mengunjungi berbagai lokasi bencana alam yang ada di Indonesia. Tujuannya untuk mengetahui secara langsung seperti apa kondisi terkini dan bagaimana nasib para korban bencana seperti saat bencana gempa di Pidie Jaya Aceh, gempa di Lombok Nusa Tenggara Barat, tsunami di Palu Sulawesi Tengah dan di sekitar Selat Sunda-Lampung-Mataram, banjir bandang dan tanah longsor di Jayapura, jatuhnya pesawat Lion Air JT-610 Jakarta-Pangkal Pinang, ambruknya jembatan lalu lintas penghubung Padang ke Bukit Tinggi Sumatera Barat. Kehadiran Presiden Jokowi tentunya akan sedikit meringankan beban para korban bencana karena secara langsung akan ada perhatian dari pemerintah pusat dan pemerintah daerah.

Salah satu kegiatan informal Presiden yakni ada dalam kategori menerima kunjungan tamu dalam negeri. Yakni, saat menerima tamu tokoh maupun masyarakat biasa. Seperti bersilaturahmi dengan warga saat acara open house di Gedung Agung Yogyakarta. Mengundang dan mengajak makan siang bersama sambil berdiskusi dengan beberapa kelompok mulai dari pegiat media sosial hingga Persatuan Guru Republik Indonesia di Istana Negara. Presiden Jokowi juga menerima kunjungan dari tokoh agama seperti Pengurus 
Nahdlatul Ulama dan Pengurus Pusat Muhammadiyah dan para kyai untuk berkumpul dan bersilaturahmi di Instana Negara dalam rangka memperkuat bangsa Indonesia. Kehadiran tokoh politik seperti Prabowo Subianto, Megawati Soekarno Putri, Romahurmuziy dan tokoh lainnya untuk berbincang-bincang dan membahas tentang isu dan masalah yang sedang terjadi di Indonesia. Saat menerima kunjungan tamu dalam negeri, ciri khas Presiden Jokowi saat menjamu tamu yaitu dengan mengajak makan siang bersama apabila tamu yang diundang cukup banyak. Dan menikmati minum teh bersama tokoh publik atau politik lainnya di beranda Istana Merdeka untuk membahas isu-isu yang sedang terjadi di Indonesia.

Unggahan yang berjumlah kurang dari 30 dikelompokkan ke dalam 8 kategori. Kalau diurutkan dari jumlah besar hingga kecil yakni kategori pertahanan dan keamanan (26), pendidikan (20), pelantikan (11), tenaga kerja (10), upacara (10), pariwisata (8), kesehatan (5) dan lingkungan hidup (5).

Unggahan pertahanan dan keamanan, antara lain memuat kegiatan Presiden Jokowi saat berkunjung atau memimpin kegiatan kemiliteran dalam rangka mempertahankan serta mengamankan kondisi Indonesia dari berbagai ancaman. Kategori pendidikan antara lain menampilkan kegiatan berkunjung ke sekolah-sekolah hingga ke perguruan tinggi untuk melihat seperti apa model pendidikan yang diajarkan hingga membagikan Kartu Indonesia Pintar kepada masyarakat yang membutuhkan. Saat berkunjung ke sekolah-sekolah untuk melihat kondisi belajar siswa-siswi, Presiden sering memberikan kuis atau pertanyaan seputar Indonesia. Apabila ada siswa yang bisa menjawab akan diberi hadiah seperti tas, buku, bahkan diberi sepeda yang menjadi ciri khas hadiah dari Presiden Jokowi. Kategori pelantikan tidak menampilkan seluruh kegiatan Presiden Jokowi saat melantik pejabat negara/ pemerintahan. Namun unggahan dalam kategori pelantikan hanya menggambarkan kegiatan Presiden saat melantik Kepala dan Wakil Kepala Pusat Pelaporan dan Analisis Transaksi Keuangan (PPATK), Marsekal TNI Hadi Tjahyanto sebagai Kepala Staf Angkatan Udara di Istana Negara. Juga memuat pelantikan lulusan Pamong Praja Muda di Jatinangor oleh Presiden Jokowi.

\section{Proses komunikasi atau kegiatan-kegiatan komunikasi}

Unggahan mencerminkan kegiatan sehari-hari Presiden Jokowi. Mulai dari melakukan kunjungan kenegaraan, menerima kunjungan kenegaraan, menerima kunjungan dari tokoh dalam negeri, meninjau pembangunan infrastruktur, kegiatan ekonomi, sosial budaya, pertahanan dan keamanan Negara, melihat kondisi pendidikan yang ada di Indonesia, kondisi tenaga kerja, kondisi kesehatan masyarakat terutama di daerah, berkunjung ke lokasi pariwisata, ikut serta dalam kegiatan lingkungan hidup, memimpin upacara, pelantikan, menyampaikan prestasi, memberi ucapan, mengunjungi lokasi bencana alam hingga menampilkan kehidupan pribadi Presiden Jokowi.

Unggahan di Instagram @jokowi tidak untuk memberitakan kegiatan Presiden Jokowi sehari-hari. Karena tidak semua kegiatan Presiden Jokowi ditampilkan. Tetapi TKDP menyediakan ruang dan mengelola komunikasi politik Presiden Jokowi melalui media sosial. Ruang komunikasi politik yang dikelola TKDP dapat dilihat dari jumlah secara kuantitas unggahan per kategori.

Dari penanyangan Instagram @jokowi, masyarakat dapat mengetahui sejauh mana perkembangan pembangunan yang dilakukan pemerintah di bidang infrastruktur melalui laporan langsung dari Presiden Jokowi maupun dari foto/ video yang ditayangkan. “... bahkan 
kita mencatat yang telah dilakukan Presiden dalam membangun infrastruktur merupakan pembangunan infrastruktur yang terbesar sepanjang sejarah Indonesia" (TKDP, 2019, p. 4). Kondisi ini selaras dengan harapan Presiden Jokowi dalam pemerataan pembangunan. Agar Nusantara dapat terhubung maka dibangun akses untuk jalan tol antarprovinsi agar lalu lintas semakin lancar. Termasuk pembangunan sarana dan prasarana publik mendapat perhatian pemerintah.

Pengelolaan ruang komunikasi politik melalui Instagram @jokowi sangat relevan dengan kelompok usia pengguna internet saat ini yaitu pada 19-34 tahun yang merupakan kelompok usia yang perlu 'digarap' di Pilpres 2019. Dan sudah terbukti, pemilih dari kelompok usia yang melek dan akrab dengan literasi melalui media sosial ini, minimal tertarik, dan menjadi pemilih, Jokowi di Pilpres 2019 lalu.

\section{Umpan balik}

Umpan balik dikaji dari respon yang terjadi dalam proses komunikasi dari unggahan Instagram @jokowi melalui komentar yang disampaikan oleh masyarakat. Terdapat ribuan komentar yang ada di unggahan Instagram @jokowi, baik yang berkomentar memuji maupun mengkritik. Tetapi tidak ada satu pun yang mendapat balasan dari pengelola akun Instagram @jokowi tersebut. TKDP hanya menyimak dan membaca segala input yang masuk. Namun untuk menjawab perlu mendapatkan koordinasi lebih lanjut.

Proses evaluasi pengelolaan Instagram @jokowi dilakukan TKDP secara rutin tiap minggu. Bahkan untuk kasus-kasus tertentu, evaluasi dapat dilakukan lebih cepat. Bisa harian bahkan dalam periode jam. Presiden Jokowi juga memberikan masukan dan terlibat langsung dalam memilih konten mana yang perlu diposting dan juga terlibat dalam proses evaluasinya.

\section{KESIMPULAN}

Audit komunikasi terhadap akun media sosial Instagram @jokowi pada periode 4 Januari 2016 hingga 23 Maret 2019 dengan 1.141 unggahan menjelaskan bahwa pengelola akun Instagram @jokowi mengelola secara rutin dengan mengunggah berbagai konten yang informatif dan terstruktur. Terdapat 19 kategori unggahan. Bila berdasarkan jumlah (besar ke kecil), ke-19 kategori unggahan tersebut adalah 1) pembangunan infrastruktur; 2) ucapan; 3) sosial budaya; 4) ekonomi; 5) rapat kerja; 6) kunjungan kenegaraan; 7) menerima kunjungan kenegaraan; 8) kehidupan pribadi; 9) prestasi; 10) bencana; 11) menerima kunjungan tamu dalam negeri; 12) pertahanan dan keamanan; 13) pendidikan; 14) pelantikan; 15) tenaga kerja; 16) upacara; 17) pariwisata; 18) kesehatan; 19) lingkungan hidup.

TKDP sebagai pengelola akun Instagram @jokowi, sebagaimana fungsi humas di lingkungan pemerintahan, berhasil menjalankan fungsi kehumasan Presiden dan menampilkan kegiatan Presiden Jokowi sebagai Presiden Republik Indonesia tanpa menyinggung atau menampilkan kegiatan politik jelang Pilpres 2019. Hal ini membuktikan bahwa Tim Komunikasi Digital Presiden bertindak dan bekerja selayaknya humas yang bekerja dalam instansi pemerintah sebagaimana telah diatur oleh Peraturan Menteri Pendayagunaan Aparatur Negara Dan Reformasi Birokrasi Republik Indonesia Nomor 30 Tahun 2011 tentang Pedoman Umum Tata Kelola Kehumasan di Lingkungan Instansi Pemerintah.

Unggahan di Instagram @jokowi tidak untuk memberitakan kegiatan Presiden Jokowi sehari-hari. Karena tidak semua kegiatan Presiden Jokowi diunggah. Tetapi TKDP menyediakan 
ruang dan mengelola komunikasi politik Presiden Jokowi melalui media sosial. Ruang komunikasi politik yang dikelola TKDP dapat dilihat dari jumlah secara kuantitas unggahan per kategori.

Di sisi lain, keberadaan Instagram @jokowi sebagai media sosial pemerintah tentunya mendapat tanggapan positif dan negatif dari masyarakat. Pengelolaan yang tepat akan memberikan dampak positif seperti tersampaikannya aspirasi dari berbagai lapisan masyarakat yang dihubungkan melalui kanal media sosial sehingga masyarakat luas bisa saling menyampaikan pendapat dan terjadilah interaksi di laman komentar.

Kajian audit komunikasi pada media sosial (Instagram, Twitter, Facebook) yang dimiliki lembaga negara, kementerian, lembaga pemerintah nonkementerian, lembaga nonstruktural, pemerintah daerah, para pejabat negara/ daerah perlu dilakukan guna memastikan apakah keberadaan media sosial menunjang tujuan lembaga masing-masing.

\section{DAFTAR PUSTAKA}

Ajo. (7 Mei 2018). Kemkominfo: Pengguna internet di Indonesia capai 82 Juta. Kominfo.go.id.https://kominfo.go.id/index.php/content/detail/3980/Kemkominfo\%3A+Peng una+Internet+di+Indonesia+Capai+82+Juta/0/berita_satker

Hardjana, A. (2000). Audit komunikasi: Teori dan praktek. Grasindo.

Hardjana, A. (2014). Audit komunikasi internal. Interact, 3(2). 1-17.

Hardjana, A. (2016). Komunikasi organisasi: Strategi dan kompetensi. Penerbit Buku Kompas.

Kriyantono, R. (2006). Teknik praktis riset komunikasi. Kencana Prenadamedia Group.

Mohammed, R. (2015). Audit komunikasi: Pendekatan dan metode asesmen sistem informasi komunikasi dalam organisasi. Prenadamedia Group.

Nistanto, R. K. (29 Januari 2016). Ini akun instagram resmi presiden jokowi. Kompas.com. https://tekno.kompas.com/read/2016/01/29/06310027/Ini.Akun.Instagram.RmiPresiden.Jokowi

Pace, R. W. (2000). Komunikasi organisasi: Strategi meningkatkan kinerja perusahaan. PT Remaja Rosdakarya.

Randle, P. (2013). Social media audit. Arlington.

Sugiyono. (2016). Memahami penelitian kualitatif. Alfabeta.

Tim Asosiasi Penyelenggara Jasa Internet Indonesia. (April 2018). Potret zaman now pengguna \& perilaku internet Indonesia. Buletin APJII, Edisi 23. https://apjii.or.id/content/read/104/357/BULETIN-APJII-EDISI-23---April-2018

Keputusan Menteri Ketenagakerjaan Republik Indonesia Nomor 105 Tahun 2015 tentang Penetapan Standar Kompetensi Kerja Nasional Indonesia Kategori Informasi Dan Komunikasi Golongan Pokok Kegiatan Jasa Informasi Pada Jabatan KerjaAuditor Komunikasi.

Peraturan Menteri Pendayagunaan Aparatur Negara dan Reformasi Birokrasi Republik Indonesia Nomor 30 Tahun 2011 tentang Pedoman Umum Tata Kelola Kehumasan di Lingkungan Instansi Pemerintah.

Peraturan Menteri Pendayagunaan Aparatur Negara dan Reformasi Birokrasi Republik Indonesia Nomor 83 Tahun 2012 tentang Pedoman Pemanfaatan Media Sosial Instansi Pemerintah.

Peraturan Menteri Negara Pendayagunaan Aparatur Negara Dan Reformasi Birokasi Republik Indonesia Nomor 27 Tahun 2011 Tentang Pedoman Umum Audit Komunikasi Di Lingkungan Instansi Pemerintah.

Tim Komunikasi Digital Presiden (TKDP) melalui surat elekktronik pada tanggal 14 Agustus 2019. 